\title{
POSSIBILITY OF REINFORCEMENT THE FUNCTIONAL POTENTIAL OF VEGETABLE JUICES WITH THE USE OF NOVEL STRAIN LACTIPLANTIBACILLUS PLANTARUM EK11 ISOLATED FROM AN UNCONVENTIONAL FERMENTED FOOD MATRIX
}

\author{
- Research paper -
}

\author{
Katarzyna SKRZYPCZAK ${ }^{1 *}$, Klaudia GUSTAW ${ }^{* *}$, Dominika SCHWONKE*, Izabela PAŁYS*, \\ Katarzyna GORDAT*, Monika MICHALAK-MAJEWSKA*, Waldemar GUSTAW* \\ *Department of Plant Food Technology and Gastronomy, Faculty of Food Science and \\ Biotechnology, University of Life Sciences in Lublin, Skromna 8, 20-704 Lublin, Poland \\ ** Department of Biotechnology, Microbiology and Human Nutrition, Faculty of Food Science and \\ Biotechnology, University of Life Sciences in Lublin, Skromna 8, 20-704 Lublin, Poland
}

\begin{abstract}
The study investigated the suitability of a novel strain Lactiplantibacillus plantarum EK11 for obtaining fermented tomato and beetroot juices with improved functional potential. EK11 had the capability of dynamic acidification of pasteurized vegetable beverages. The lowest values of $\mathrm{pH}$ were noted in juices after $48 \mathrm{~h}$ of fermentation with the probiotic L. plantarum $299 \mathrm{v}(\mathrm{pH}=3.72 \pm 0.01$ in beet juice and $\mathrm{pH}=3.43 \pm .0 .01$ in tomato juice). The fermentation increased the lycopene content in tomato juices from $27.90 \pm 0.31 \mu \mathrm{g} \mathrm{mL}^{-1}$ (after 24 -h fermentation by strain EK11) to $116.86 \pm 0.19 \mu \mathrm{g} \mathrm{mL}^{-1}$ (final products obtained using strain $299 \mathrm{v}$ after 7 -day cold storage). The process contributed to changes in the betanin and vulgaxanthin-I concentration in beetroot beverages. All fermented products exhibited antioxidative activity, i.e. 50\% inhibition of 1,1-diphenyl-2-picrylhydrazyl free radicals. Moreover, three genes involved in the biosynthesis of bacteriocins were detected in the novel strain EK11, which exhibits functional and technological potential for the production of fermented foods.
\end{abstract}

Keywords: lactic acid fermentation, bacteriocins, functional food

\section{INTRODUCTION}

Lactic acid fermentation is recognized as an alternative to heat treatment or chemical preservatives ensuring the high quality and safety of plant-derived raw material and contributing to positive changes in the food matrix (Di Cagno et al., 2016). Moreover, this bio-preservation method increases the availability of health-promoting components and improves the sensory features of foodstuffs (Torres et al., 2020).

Nowadays, fermented plant-based products are perceived as high nutritional and functional foodstuffs contributing to beneficial health effects. With their desirable effect on human health, fermented plant-derived products are the subject of many scientific studies and the focus of consumers' interest, particularly in "healthconscious" developed countries (Torres et al., 2020).

Received: 26.03.2021

Accepted in revised form: 11.05.2021
The manufacture of fermented vegetables or/and fruits is often based on technologies with longstanding traditions that largely determine the specific attributes of the final products. However, spontaneous fermentation processes pose a risk of failure, especially the emergence of adverse changes in the nutritional composition, insufficient prevention of spoilage, undesirable sensory features, or the development of pathogenic microorganisms. Therefore, controlled fermentation based on well-characterized starter cultures is strongly recommended (Di Cagno et al., 2013). The use of starter cultures of autochthonous microorganisms (isolated from raw plant material or wild fermentation products) adapted to the peculiar environmental conditions and specificity of the food matrix may ensure the proper flow of the technological process and yield reproducible high-quality products with appropriate organoleptic and sensory parameters and

${ }^{1}$ Corresponding authors. E-Mail address: katarzyna.skrzypczak@up.lublin.pl 
functional properties (Vera-Pingitore et al., 2016; Torres et al., 2020). Therefore, there is a growing need for seeking new niches and sources of microorganisms with technological features and unique probiotic attributes relevant in the fermented food industry, pharmacy, or medicine. In recent years, many investigations have focused on the isolation and selection of autochthonous plant microorganisms (especially lactic acid bacteria, LAB) exhibiting the desired characteristics (Szutowska and Gwiazdowska 2020). However, spontaneously fermented

\section{MATERIALS AND METHODS}

\section{Bacteria culture conditions and molecular analysis}

The Lactiplantibacillus plantarum EK11 strain that was previously isolated from spontaneously fermented Agaricus bisporus (Skrzypczak et al., 2020) and deposited in the strain collection of the Department of Plant Food Technology and Gastronomy (Faculty of Food Science and Biotechnology, University of Life Sciences in Lublin, Poland) was used in the study. In turn, the probiotic L. plantarum 299v (Sanprobi IBS, Sanum Poland) was used as a control strain to compare the analyzed bacterial features. The microbial cultures were kept at $-80^{\circ} \mathrm{C}$ as a stock solution that contained $15 \%$ glycerol. Before analysis, the strains were systematically propagated by transferring $(2 \% \mathrm{v} / \mathrm{v})$ into fresh and sterile ManRogosa-Sharpe (MRS) broth (BTL, Poland) and incubated in anaerobic conditions at $37^{\circ} \mathrm{C}$ for $18 \mathrm{~h}$ (Galanis et al., 2015).

Molecular analysis was performed to verify the phylogenetic affiliation of the novel strain. Briefly, the extraction of genomic DNA was performed applying Genomic Mini AX Bacteria Spin (A\&A Biotechnology, Gdynia, Poland) according to the manufacturer's protocol. Next, 16S rRNA was amplified using universal primers (27f) 5AGAGTTTGATCCTGGCTCAG-3 and (1495r) 5'-CTACGGCTACCTTGTTACGA-3` (Genomed S.A., Warsaw, Poland). The mixture of PCR reaction $(25 \mu \mathrm{l})$ contained $100 \mathrm{ng} \mu \mathrm{L}^{-1}$ of genomic DNA, 20 pmol of each starter, $12.5 \mu \mathrm{L}$ of DreamTaq Green PCR Master Mix (2X) (Thermo Scientific, Waltham, MA, USA), adjusted to the final volume by nuclease-free water. The reaction was performed using a Labcycler (SensoQuest, Göttingen, Germany) in the following steps: denaturation $\left(4 \mathrm{~min} / 95^{\circ} \mathrm{C}\right) ; 30$ cycles consisting of denaturation $\left(95^{\circ} \mathrm{C} / 30 \mathrm{~s}\right)$, annealing at $48^{\circ} \mathrm{C} / 30 \mathrm{~s}$, and elongation $\left(72^{\circ} \mathrm{C} / 30 \mathrm{~s}\right)$; final extension $(8$ $\min / 72^{\circ} \mathrm{C}$ ), afterward the samples were cooled mushrooms as a source of new LAB isolates to be used as a starter culture in the fermentation industry still seem to be unexplored (JabłońskaRyś et al., 2019). Therefore, the objective of this investigation was to determine the suitability of the novel strain of Lactiplantibacillus plantarum EK11 (isolated previously from fruiting bodies of white button mushrooms after spontaneous fermentation) in the production of fermented tomato and beetroot juices with enhanced health-promoting potential and improved functional properties.

down up to $4^{\circ} \mathrm{C}$. The products of amplification were electrophoretically separated in $1 \%$ agarose gel (BASICA LE, Prona Agarose) that contained 0.25\% Midori Green DNA Stain (Nippon Genetics Europe, Dueren, Germany). The electrophoresis was performed for $1 \mathrm{~h}$ (at $60 \mathrm{~V}$ ) using TBE buffer, visualized under UV illumination, and photographed using a digital camera (GelDoc XR+ Imaging System, BioRad, USA). The obtained products were cut out of gel, purified, and sequenced applying a BigDye Terminator v3.1 Cycle Sequencing Kit (Applied Biosystems, USA) using the capillary 3730xl DNA Analyzer sequencing system (Applied Biosystems, USA). Then the obtained nucleotide sequences were further analyzed using a DNA Baser Sequence, while BLAST (National Center for Biotechnology Information,

USA, http://www.ncbi.nlm.nih.gov/blast) was applied to align the sequences. Thereafter, the tested sequence was deposited in GenBank with accession number MW040528 and compared with other gene sequences available in the GenBank database.

\section{Detection of genes encoding selected bacteriocins}

Specific primers (Table 1) were used for PCR reactions to detect genes (in the plantaricin locus) that are relevant for the biosynthesis of bacteriocins.

Each PCR mixture contained $10 \mu \mathrm{L}$ of DreamTaq Green PCR Master Mix (2X) (Thermo Scientific, Waltham, MA, USA), $1 \mu \mathrm{M}$ of both primers, $50 \mathrm{ng}$ of template DNA, and nuclease-free water (adjusted to the final volume). The PCR reactions were performed as in Rizzello et al. (2014) in a Labcycler (SensoQuest Göttingen, Germany) in the following conditions: denaturation at $94^{\circ} \mathrm{C}$ for 2 min; 30 cycles of denaturation $\left(94^{\circ} \mathrm{C}\right.$ for $\left.15 \mathrm{~s}\right)$, annealing $\left(60^{\circ} \mathrm{C}\right.$ for $\left.30 \mathrm{~s}\right)$, and elongation $\left(72^{\circ} \mathrm{C}\right.$ for $2 \mathrm{~min}$ ); final polymerization at $72^{\circ} \mathrm{C}$ for $4 \mathrm{~min}$. 
Table 1. The oligonucleotides applied to detect genes belonging to the $p \ln$ locus.

\begin{tabular}{|c|c|c|c|c|c|c|}
\hline $\begin{array}{l}\text { Target } \\
\text { gene }\end{array}$ & $\begin{array}{c}\text { Encoded } \\
\text { bacteriocin }\end{array}$ & $\begin{array}{l}\text { Forward } \\
\text { Primer } \\
\left(5^{\prime}->3^{\prime}\right) \\
\end{array}$ & $\begin{array}{l}\text { Reverse } \\
\text { Primer } \\
\left(5^{\prime}->3^{\prime}\right) \\
\end{array}$ & $\begin{array}{l}\text { Annealing } \\
\text { temp. } \\
\left({ }^{\circ} \mathrm{C}\right) \\
\end{array}$ & $\begin{array}{l}\text { Size of } \\
\text { amplic } \\
\text { on (bp) }\end{array}$ & References \\
\hline$p \ln \mathrm{EF}$ & $\begin{array}{c}\text { Plantaricin } \\
\text { EF }\end{array}$ & $\begin{array}{c}\text { GGCATA } \\
\text { GTTAAA } \\
\text { ATTCCC } \\
\text { CCC }\end{array}$ & $\begin{array}{c}\text { CAGGT } \\
\text { TGCCG } \\
\text { CAAAA } \\
\text { AAAG }\end{array}$ & 53.2 & 428 & Rizello et al., 2014. \\
\hline$p \ln \mathrm{A}$ & $\begin{array}{c}\text { Plantaricin } \\
\text { A }\end{array}$ & $\begin{array}{l}\text { GTACAG } \\
\text { TACTAA } \\
\text { TGGGAG }\end{array}$ & $\begin{array}{c}\text { CTTAC } \\
\text { GCCAT } \\
\text { CTATA } \\
\text { CG }\end{array}$ & 53 & 450 & $\begin{array}{c}\text { Rizello et al., 2014; } \\
\text { Rojo-Bezares et al., } \\
2007 .\end{array}$ \\
\hline$p \ln \mathrm{G}$ & $\begin{array}{c}\text { Plantaricin } \\
\text { G }\end{array}$ & $\begin{array}{c}\text { TGCGGT } \\
\text { TATCAG } \\
\text { TATGTC } \\
\text { AAAG }\end{array}$ & $\begin{array}{c}\text { CCTCG } \\
\text { AAACA } \\
\text { ATTTC } \\
\text { CCCC }\end{array}$ & 52,8 & 453 & $\begin{array}{c}\text { Rizello et al., 2014; } \\
\text { Rojo-Bezares et al., } \\
2007 .\end{array}$ \\
\hline
\end{tabular}

The amplification products were separated by electrophoresis on $1.5 \%$ (wt/vol) agarose gel with visualization and archivization of results as described above.

\section{Preparation of vegetable juices}

The roots of red beet (Beta vulgaris subsp. vulgari) variety Opolski purchased in a local store in Lublin (place of cultivation: A farm in Janów Lubelski, Lublin Province, Poland). The juice was obtained with the methodology described by Panghal et al. (2017) with some modifications. The roots were washed, peeled, and rinsed again. Fresh juice was obtained using a juice extractor (Juice Master Professional Juicer, Zelmer, Germany). Fresh raspberry tomatoes (Solanum lycopersicum L.) purchased at a local market were used for the production of the second variant of juice.

The tomato juice was obtained as in El-Sayed et al. (2018). The fresh tomatoes were carefully washed (under running tap water) to remove impurities, blanched (in the water at $85^{\circ} \mathrm{C}$ for 1 minute) to improve the removal of the skin, and blended using a hand blender (BOSCH ErgoMixx MSM67140, RBH GmbH, Germany). The mass was filtered through the cheesecloth and the filtrate was used in further analyses.

Each variant of the drinks was divided into six equal $250-\mathrm{mL}$ portions, transferred into sterile unit packs (twisted glass bottles), and pasteurized in a water bath $\left(85^{\circ} \mathrm{C} / 10 \mathrm{~min}\right)$. After cooling to ambient temperature, they were used as a base material for fermentation.

\section{Preparation of inoculums and fermentation conditions}

Directly after the 18-h incubation of the bacterial cultures (L. plantarum EK11 and 299v), the biomasses of each strain were collected separately by centrifugation $\left(8000 \quad \mathrm{x} \quad \mathrm{g} / 10 \mathrm{~min} / 4^{\circ} \mathrm{C}\right)$. Supernatants were removed and the pellets were washed with a sterile saline solution $(0.85 \%)$. The pellets resuspended in saline (in a volume equal to the initial size of collected culture cell suspensions) were centrifuged $(8000 \mathrm{x} \quad \mathrm{g} / 10$ $\mathrm{min} / 4^{\circ} \mathrm{C}$ ) and the supernatants were removed. The procedure of washing the pellets was repeated twice. The final pellets were resuspended in a sterile $\mathrm{NaCl}$ solution $(0.85 \%)$ in an amount corresponding to the initial volumes of the strain cultures. Then, the proper inoculums $\left(\mathrm{OD}_{550}=0.50\right)$ of each strain were prepared and incorporated (1\% $\mathrm{vol} / \mathrm{vol}$ ) into the vegetable juices variants (all steps were performed in sterile conditions). Noninoculated drinks were the control samples. The process of fermentation was carried out for $48 \mathrm{~h}$ at $37^{\circ} \mathrm{C}$ (in anaerobic conditions).

The samples of beverages were collected (for further analysis) at equal time intervals (after $24 \mathrm{~h}$ and $48 \mathrm{~h}$ of incubation). After fermentation, the samples were transferred to $4^{\circ} \mathrm{C}$ and maintained for 7 days. Next, they were collected for the determination of changes in the fermented drinks after refrigeration storage.

Changes in the $\mathrm{pH}$ values in the tested juices during fermentation (at the indicated time intervals) were monitored using a $\mathrm{pH}$ meter (Hanna Instruments HI 221, Hanna Instruments, Poland). The water activity $\left(\mathrm{a}_{\mathrm{w}}\right)$ values were determined using a dedicated device (LabSwift-aw, Novasina, Switzerland) according to the manufacturer's instructions. The total extract content in the juices was determined with the refractometer method according to PN-90/A$75101 / 02$. The refractive index of the tested beverages was measured with a refractometer 
(Kruss DR201-95 Merazet, Poland) and its values were expressed in Brix degrees $\left({ }^{\circ} \mathrm{Bx}\right)$. The measurements were performed in six repetitions for all beverage variants.

Before further biochemical determinations, the tested samples were heated at $95^{\circ} \mathrm{C}$ for $5 \mathrm{~min}$ to inactivate bacteria and inhibit enzymatic activity.

\section{Analysis of fermented products \\ The total content of polyphenolic compounds}

The total content of polyphenolic compounds (TPC) in the analyzed juice samples was determined with the spectrophotometric method using Folin-Ciocalteu reagent (F-C) as in Guldiken et al. (2016). Briefly, $1 \mathrm{~mL}$ of freshly prepared F-C reagent was added to each juice sample $(200 \mu \mathrm{L})$. Afterward, $0.8 \mathrm{~mL}$ of a sodium carbonate solution $(7.5 \%)$ was added and the samples were thoroughly mixed and incubated for $30 \mathrm{~min}$. at room temperature in darkness.

After incubation, directly before spectrophotometric measurements, the samples were centrifuged $\left(12000 \mathrm{x} \mathrm{g} / 5 \mathrm{~min} / 4^{\circ} \mathrm{C}\right.$; Eppendorf Centrifuge 5415R, Germany). The values of absorbance (of clarified solutions) were measured at $\lambda=765 \mathrm{~nm}$ (Spectrophotometer UVVis Helios Gamma Thermo, USA).

The content of polyphenolic compounds was calculated from the calibration curve (prepared for standard solutions of gallic acid) and expressed in $\mu \mathrm{g} \mathrm{mL} \mathrm{L}^{-1}$ of juice. The determinations were performed in six repetitions for all tested samples.

\section{Determination of the total content of flavonoid compounds}

The total content of flavonoid compounds (TFC) in the fermented and control juice samples was determined as in Guldiken et al. (2016) with some modifications. Briefly, $1 \mathrm{~mL}$ of the sample was mixed with $4 \mathrm{~mL}$ of distilled water and $150 \mu \mathrm{L}$ of $5 \% \quad \mathrm{NaNO}_{2}$. After 5-min incubation (at ambient temperature), $150 \mu \mathrm{L}$ of an $\mathrm{AlCl}_{3}$ solution (10\%) was added. After 6-min incubation, $2 \mathrm{~mL}$ of a sodium hydroxide solution $(1 \mathrm{M})$ were added and the mixture was thoroughly mixed. Immediately before spectrophotometric measurements, the samples were centrifuged $\left(12000 \mathrm{x} \mathrm{g} / 5 \mathrm{~min} / 4^{\circ} \mathrm{C}\right)$ and absorbance values were measured (in clarified solutions) at $\lambda=510 \mathrm{~nm}$ (Spectrophotometer UVVis Helios Gamma Thermo, USA). The content of flavonoid compounds was calculated from the calibration curve prepared for the number of quercetin standard solutions and expressed in $\mu \mathrm{g}$ per $\mathrm{mL}$ of juice.

\section{Determination of the content of betalains in beetroot juices}

The content of betalains pigments in the beetroot juice samples was determined as in Gościnna et al. (2012).

The fermented and non-fermented beetroot juice samples were diluted with phosphate buffer $(\mathrm{pH}$ 6.5) to obtain an absorbance value in the range of $0.2-0.8$. Absorbance was measured at three wavelengths: $\lambda=476 \mathrm{~nm}, \lambda=538 \mathrm{~nm}$, and $\lambda=600 \mathrm{~nm}$ (Spectrophotometer UV-Vis Helios Gamma Thermo, USA).

The concentrations of betanin and vulgaxanthin-I in the beetroot beverages were calculated from the following equations (Halwni et al., 2018):

$$
\begin{aligned}
& x=1.095 \cdot(a-c) \\
& z=a-x \\
& y=(b-z)-(x / 3.1)
\end{aligned}
$$

where: $\mathrm{a}=$ absorption of the sample at $\lambda=538 \mathrm{~nm}$; $\mathrm{b}=$ absorption of the sample at $\lambda=476 \mathrm{~nm}$; $\mathrm{c}=$ absorption of the sample at $\lambda=600 \mathrm{~nm}$; $\mathrm{x}=\mathrm{absorption}$ of betanin minus color impurities, $y=1$ absorption of vulgaxanthin -1 corrected for the contribution of betanin and color impurities, $\mathrm{z}=$ light absorption of impurities; $\mathrm{x}=$ absorbance of betanin corrected for the proportion of color impurities

The determinations were made in twelve repetitions (for each beetroot drink) and the results were expressed as $\mathrm{mg}$ of betalains pigments per $\mathrm{mL}$ of beverage.

\section{Determination of the content of lycopene in tomato juices}

The lycopene content in the tomato juices (fermented and unfermented) was determined as described by Suwanaruang (2016). Lycopene was extracted based on the method developed by Adejo et al. (2015). In brief, the beverage samples $(0.001$ g) were diluted by adding $1 \mathrm{~mL}$ of distilled water, thoroughly mixed, and incubated in a water bath $\left(30^{\circ} \mathrm{C} / 60 \mathrm{~min}\right)$. Then, $8 \mathrm{~mL}$ of hexane:ethanol: acetone (2:1:1) mixture were added and, after sealing tightly, the samples were thoroughly mixed and incubated in the dark for $30 \mathrm{~min}$ (at room temperature). Afterwards, $1 \mathrm{~mL}$ of distilled water was added to each sample, which was subsequently mixed and left for $10 \mathrm{~min}$ at room temperature (in the dark) for phase separation.

The absorbance of the samples was measured spectrophotometrically at $\lambda=503 \mathrm{~nm}$. The concentration of lycopene in hexane extracts was calculated using the formula (Suwanaruang, 2016): Lycopene content $\left[\mathrm{mg} \mathrm{kg}^{-1}\right]=A_{503 \mathrm{~mm}} \times 537 \times 8 \times$ $0.55 / 0.10 \times 172$ 
The analysis was performed in six repetitions (for each tomato product).

\section{Antioxidant activity assay} vegetable beverages were assessed with the methodology described by El-Fattah et al. (2016). Juice samples $(10 \mathrm{~mL})$ were mixed with $40 \mathrm{~mL}$ of distilled water. After sealing, the samples were shaken at room temperature for $30 \mathrm{~min}$ and centrifuged at $10000 \mathrm{x} \mathrm{g} / 30 \mathrm{~min}$. Each of $1 \mathrm{~mL}$ of clear supernatant (tested samples) was supplemented with $1 \mathrm{~mL}$ of a $0.1 \mathrm{mmol} \mathrm{L}^{-1}$ free radical solution (in $96 \%$ ethanol) of 1,1-diphenyl2-picrylhydrazyl (DPPH). Next, the samples were thoroughly mixed, incubated in the darkness (at ambient temperature for $30 \mathrm{~min}$ ), and subjected to absorbance measurements $(\lambda=517 \mathrm{~nm})$ with the use

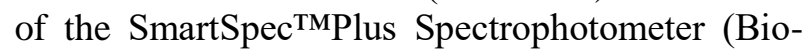

\section{RESULTS AND DISCUSSION}

\section{Detection of genes encoding selected bacteriocins}

The comparison of the 16s rRNA gene sequence with the sequences deposited in the NCBI GeneBank database exhibited the highest similarity $(99.86 \%)$ of the sequence to the $L$. plantarum TMW strain (1.1308 chromosome, complete genome of the L. plantarum strain SRCM101511 chromosome, complete genome; ref CP028235.1). The electrophoretic separation of the $\operatorname{pln} \mathrm{A}$ gene amplification products revealed the presence of specific amplicons (approximately $450 \mathrm{bp}$ ) in both analyzed strains (Figure 1. A). Additionally, products with similar molecular masses (Figure 1 $\mathrm{B}$ and $\mathrm{C}$ ) were detected after electrophoresis of the
The free radical scavenging properties of the

Rad Laboratories, Hercules, California). Ascorbic acid $\left(0.2 \mathrm{mM} \mathrm{L}^{-1}\right)$ was used as a positive control.

The free radical scavenging activities of the beverages were expressed as \% inhibition of $\mathrm{DPPH}$ absorbance $(\lambda=517 \mathrm{~nm})$ calculated from the equation below:

Inhibition [\%] $=\left[\left(A_{\text {control }}-A_{\text {test }}\right) / A_{\text {control }}\right] \times 100$ where: $A_{\text {control }}$ - absorbance of the DPPH free radical solution; $A_{\text {test }}$ - absorbance of the juice sample

The determinations were performed in nine repetitions for all tested samples.

\section{Statistical analysis}

The analyses were carried out applying STATISTICA 13.1 program (StatSoft, Inc., USA) using Tukey's HSD test in the analysis of variance (ANOVA) to determine the significance of the differences between the mean values (at $\mathrm{p}<0.05)$.

$p \ln \mathrm{G}$ and $p \ln \mathrm{EF}$ amplification products ( $p \ln \mathrm{EF}$ gene encoding dipeptide plantaricin EF). The results revealed that $L$. plantarum EK11 (similarly to the probiotic strain $299 \mathrm{v}$ ) has genetic determinants facilitating the biosynthesis of three bacteriocins (plantaricin $\mathrm{EF}$, plantaricin $\mathrm{A}$, and plantaricin G).

It has been indicated that bacteriocins produced by L. plantarum (plantaricins) exhibit strong antimicrobial activity against Listeria monocytogenes, a common pathogen found in food (Kumariya et al., 2019). Moreover, interdisciplinary investigations are focused on the implementation of these bacteriocins in anticancer therapies, new biotherapeutics, and dietary supplements for patients with inflammatory bowel diseases (Yang et al., 2014).

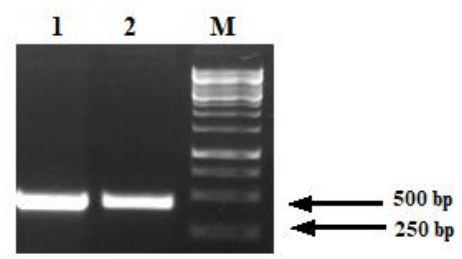

B

A
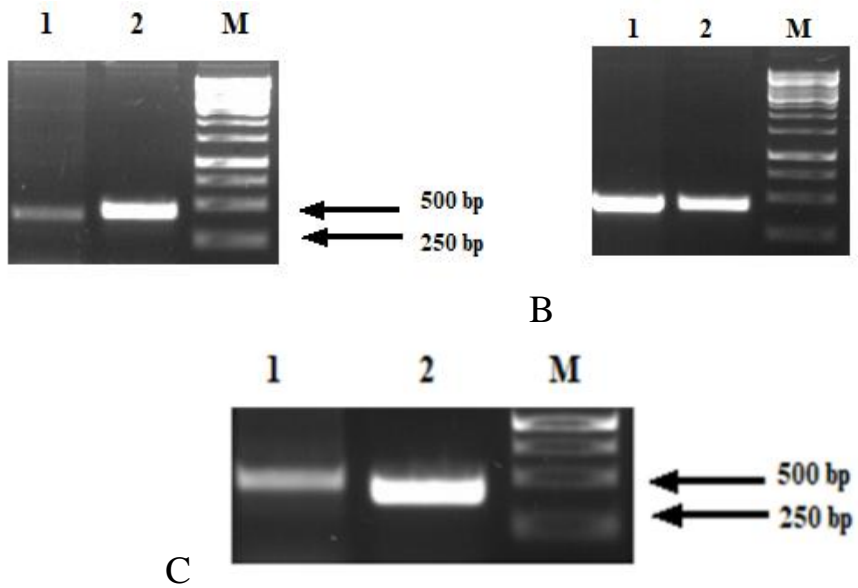

Figure 1. Products of amplification reactions: A) the $p \ln \mathrm{A}$ gene; B) the $p \ln G$ gene; C) the $p \ln \operatorname{EF}$ gene (Line $1-L$. plantarum EK11; Line 2 - L. plantarum 299v; M- molecular mass marker: GeneRuler 1 kB plus DNA Ladder, ready to use, Thermo Scientific ${ }^{\mathrm{TM}}$, USA). 
Therefore, the present results are particularly important. The new L. plantarum EK11 strain analyzed in our study exhibits genetic predisposition for the production of three important bacteriocins (PlnG, PlnEF, and PlnA). The biosynthesis of plantaricin $\mathrm{J}(\mathrm{PlnJ})$ and plantaricin $\mathrm{K}$ is induced by the activity of plantaricin $\mathrm{A}$ (PlnA), which determines the proper functioning of the $\mathrm{ABC}$ transporter responsible for plantaricins transport outside the cell (Anderssen et al., 1998; Mustopa et al., 2016). This indicates a direct association between the number of genes involved in the biosynthesis of plantaricins in a bacterial strain and its bactericidal or bacteriostatic potential against specific pathogens (Rizello et al., 2014;). Therefore, it may be suggested that L. plantarum EK11 has a high antimicrobial potential, which should be comprehensively analyzed to determine its application in the food industry. The preliminary results are relevant, given the novel concept of fermentation perceived as an alternative and relatively cheap method (vs. application of commercial enzymes) for enhancement of the food nutraceutical value (Acosta-Estrada et al., 2014).

\section{Analysis of fermented products}

The health-promoting properties of LABfermented vegetable juices are related to the content of bioactive substances, including polyphenols. However, the total polyphenol content in vegetable juices varies after lactic acid fermentation (Table 2 and Table 3).

The highest values of TPC were noted for the final products after the refrigerated storage (Table 2). Moreover, the beverages produced using the new strain EK11 had a higher concentration of TPC than those fermented by the probiotic strain. A lower level of polyphenols was observed in the tomato products fermented for $24 \mathrm{~h}$ and $48 \mathrm{~h}$ (Table 2) than in the unfermented variant (control). The total content of polyphenolic compounds (Table 3) in all fermented beetroot juices was higher than in the control variant, but these differences were not statistically significant ( $p<0.05)$. The highest level of TPC $(212.56 \pm 8.12$ $\mu \mathrm{g} \mathrm{mL} \mathrm{m}^{-1}$ ) was noticed in the beetroot-derived final products (with the probiotic strain) after 7 days of refrigerated storage.

The changes in TPC may be associated with the various enzymatic reactions occurring during fermentation and contributing to an increasing in the concentration of free phenolics released from their glycosides or other conjugates (Hur et al., 2014). In addition, the decreasing $\mathrm{pH}$ level (during fermentation) has a positive effect on the stability of phenols in plant-derived products (Garcia et al., 2020). The changes in the $\mathrm{pH}$ level in the tomato drinks induced by fermentation correspond to the results obtained by Yoon et al. (2004), who fermented tomato juice using different probiotic strains of L. acidophilus, L. plantarum, L. casei, and $L$. delbrueckii. They noticed that, although the tomato beverages had low $\mathrm{pH}$ (4.1), the cultures were able to reduce this parameter to $\mathrm{pH}=3.5$ after $72 \mathrm{~h}$ of fermentation. In our study, both strains actively fermented the tomato juices and reduced the initial pH of the drinks from 4.35 to 3.46 (strain EK11) and 3.43 (strain 299v) after 48 h. However, the application of the probiotic strain yielded beverages with lower $\mathrm{pH}$ than the products fermented by strain EK11 (Table 2 and Table 3). The lowest values of this parameter were noted after 48-h fermentation by strain $299 \mathrm{v}$ $(\mathrm{pH}=3.72 \pm 0.01$ in beetroot juice and $\mathrm{pH}=3.43 \pm .0 .01$ in tomato juice).

Table 2. Results of analyses of tomato juice.

\begin{tabular}{|c|c|c|c|c|c|c|c|}
\hline & \multirow{2}{*}{$\begin{array}{l}\text { Control } \\
\text { variant of } \\
\text { tomato } \\
\text { juice }\end{array}$} & \multicolumn{3}{|c|}{$\begin{array}{l}\text { Tomato juice fermented by L. plantarum } \\
\text { EK11 }\end{array}$} & \multicolumn{3}{|c|}{$\begin{array}{c}\text { Tomato juice fermented by L. plantarum } \\
299 \mathrm{v}\end{array}$} \\
\hline & & $\begin{array}{l}\text { After } \\
24 \mathrm{~h}\end{array}$ & $\begin{array}{l}\text { After } \\
48 \mathrm{~h}\end{array}$ & $\begin{array}{l}\text { After } 7 \text { days of } \\
\text { cold storage }\end{array}$ & $\begin{array}{l}\text { After } \\
24 \mathrm{~h}\end{array}$ & $\begin{array}{l}\text { After } \\
48 \mathrm{~h}\end{array}$ & $\begin{array}{l}\text { After } 7 \text { days of } \\
\text { cold storage }\end{array}$ \\
\hline $\mathrm{pH}$ & $\begin{aligned} & 4.35 \\
& \pm 0.03^{\mathrm{d}} \\
&\end{aligned}$ & $\begin{array}{r}3.61 \\
\pm 0.03^{\mathrm{c}} \\
\end{array}$ & $\begin{array}{r}3.46 \\
\pm 0.02^{\mathrm{a}} \\
\end{array}$ & $\begin{array}{r}3.46 \\
\pm 0.02^{\mathrm{a}} \\
0\end{array}$ & $\begin{array}{c}3.53 \\
\pm 0.02^{\mathrm{b}} \\
\end{array}$ & $\begin{aligned} & 3.43 \\
& \pm .0 .01^{\mathrm{a}} \\
&\end{aligned}$ & $\begin{array}{c}3.44 \\
\pm 0.01^{\mathrm{a}} \\
\end{array}$ \\
\hline $\begin{array}{c}\mathrm{TPC} \\
{\left[\mu \mathrm{g} \mathrm{mL}^{-1}\right]}\end{array}$ & $\begin{array}{r}81.83 \\
\pm 2.62^{\mathrm{c}} \\
\end{array}$ & $\begin{array}{r}74.46 \\
\pm 4.33^{\mathrm{b}} \\
\end{array}$ & $\begin{array}{r}66.58 \\
\pm 1.26^{\mathrm{a}} \\
\end{array}$ & $\begin{array}{r}88.21 \\
\pm 1.87^{\mathrm{d}} \\
\end{array}$ & $\begin{array}{r}74.47 \\
\pm 3.96^{\mathrm{b}} \\
\end{array}$ & $\begin{array}{l}65.69 \\
\pm 0.43^{\mathrm{a}} \\
\end{array}$ & $\begin{array}{r}86.60 \\
\pm 2.79^{d} \\
\end{array}$ \\
\hline $\begin{array}{c}\text { TFC } \\
{\left[\mathrm{mg} 100 \mathrm{~mL}^{-1}\right]}\end{array}$ & $\begin{array}{r}4.82 \\
\pm 0.12^{\mathrm{a}}\end{array}$ & $\begin{array}{r}9.34 \\
\pm 1.36 \\
\end{array}$ & $\begin{aligned} 7.92 \\
\pm 0.78^{\mathrm{b}}\end{aligned}$ & $\begin{array}{c}40.0 \\
\pm 3.60^{\mathrm{f}}\end{array}$ & $\begin{array}{l}11.77 \\
\pm 0.48^{\mathrm{cd}}\end{array}$ & $\begin{array}{r}10.26 \\
\pm 0.82^{\mathrm{d}}\end{array}$ & $\begin{array}{l}37.21 \\
\pm 2.36^{\mathrm{e}}\end{array}$ \\
\hline TEC $\left[{ }^{\circ} \mathrm{Bx}\right]$ & $\begin{aligned} 3.46 \\
\pm 0.24^{\mathrm{d}}\end{aligned}$ & $\begin{array}{c}3.17 \\
\pm 0.06^{\mathrm{c}}\end{array}$ & $\begin{array}{c}2.67 \\
\pm 0.06^{\mathrm{b}}\end{array}$ & $\begin{array}{c}1.93 \\
\pm 0.10^{\mathrm{a}}\end{array}$ & $\begin{array}{c}3.15 \\
\pm 0.06^{\mathrm{c}}\end{array}$ & $\begin{array}{c}2.75 \\
\pm 0.06^{\mathrm{b}}\end{array}$ & $\begin{array}{c}2.10 \\
\pm 0.06^{\mathrm{a}}\end{array}$ \\
\hline $\mathrm{a}_{\mathrm{w}}$ & $\begin{array}{c}0.998 \\
\pm 0.001^{\mathrm{b}}\end{array}$ & $\begin{array}{c}0.998 \\
\pm 0.001^{b}\end{array}$ & $\begin{array}{r}0.998 \\
\pm .001^{\mathrm{b}}\end{array}$ & $\begin{array}{r}0.995 \\
\pm 0.01^{\text {a }} \\
\end{array}$ & $\begin{array}{c}0.998 \\
\pm 0.001^{\mathrm{b}}\end{array}$ & $\begin{array}{c}0.998 \\
\pm 0.01^{\mathrm{b}}\end{array}$ & $\begin{array}{r}0.995 \\
\pm 0.01^{\text {a }} \\
\end{array}$ \\
\hline $\begin{array}{l}\text { Licopen content } \\
{\left[\mu \mathrm{g} \mathrm{mL}^{-1}\right]}\end{array}$ & $\begin{array}{r}18.40 \\
\pm 0.07^{\mathrm{a}}\end{array}$ & $\begin{array}{r}27.90 \\
\pm 0.31^{\mathrm{b}}\end{array}$ & $\begin{array}{r}69.41 \\
\pm 1.04^{\mathrm{d}}\end{array}$ & $\begin{array}{l}97.43 \\
\pm 0.08^{\mathrm{e}}\end{array}$ & $\begin{array}{c}27.09 \\
\pm 0.36^{\mathrm{b}}\end{array}$ & $\begin{array}{l}51.84 \\
\pm 0.10^{\mathrm{c}}\end{array}$ & $\begin{array}{l}116.86 \\
\pm 0.19^{\mathrm{f}}\end{array}$ \\
\hline
\end{tabular}

Explanatory notes: TPC - total content of polyphenolic compounds; TFC - total content of flavonoid compounds; TEC total extract content; $\mathrm{a}_{\mathrm{w}}-$ water activity. The results are presented as mean values with error bars representing standard deviation $(\overline{\mathrm{x}} \pm \mathrm{s} / \mathrm{SD})$. The differences between the mean values indicated by the different letters in the same row (analyzed parameter) are statistically significant $(\mathrm{p}<0.05)$. 
Table 3. Results of analyses of beetroot juice

\begin{tabular}{|c|c|c|c|c|c|c|c|}
\hline & \multirow{2}{*}{$\begin{array}{c}\text { Control } \\
\text { variant of } \\
\text { beetroot } \\
\text { juice }\end{array}$} & \multicolumn{3}{|c|}{$\begin{array}{l}\text { Beetroot juice fermented by } L \text {. } \\
\text { plantarum EK } 11\end{array}$} & \multicolumn{3}{|c|}{$\begin{array}{l}\text { Beetroot juice fermented by } L \text {. } \\
\text { plantarum } 299 \mathrm{v}\end{array}$} \\
\hline & & $\begin{array}{l}\text { After } \\
24 \mathrm{~h}\end{array}$ & $\begin{array}{l}\text { After } \\
48 \mathrm{~h}\end{array}$ & $\begin{array}{l}\text { After } 7 \text { days of } \\
\text { cold storage }\end{array}$ & $\begin{array}{l}\text { After } \\
24 \mathrm{~h} \\
\end{array}$ & $\begin{array}{l}\text { After } \\
48 \mathrm{~h}\end{array}$ & $\begin{array}{l}\text { After } 7 \text { days of } \\
\text { cold storage }\end{array}$ \\
\hline \multirow{2}{*}{$\mathrm{pH}$} & 6.11 & 3.85 & 3.76 & 3.76 & 3.82 & 3.72 & 3.74 \\
\hline & $\pm 0.01^{\mathrm{e}}$ & $\pm 0.02^{\mathrm{d}}$ & $\pm 0.03^{\mathrm{b}}$ & $\pm 0.01^{\mathrm{b}}$ & $\pm 0.01^{\mathrm{c}}$ & $\pm 0.01^{\mathrm{a}}$ & $\pm 0.0 .1^{\mathrm{ab}}$ \\
\hline \multirow{2}{*}{$\begin{array}{c}\mathrm{TPC} \\
{\left[\mu \mathrm{g} \mathrm{mL}^{-1}\right]}\end{array}$} & 190.25 & 206.84 & 196.71 & 204.03 & 190.34 & 195.29 & 212.56 \\
\hline & $\pm 34.38^{\mathrm{a}}$ & $\pm 17.56^{\mathrm{a}}$ & $\pm 30.44^{\mathrm{a}}$ & $\pm 22.82^{\mathrm{a}}$ & $\pm 30.97^{\mathrm{a}}$ & $\pm 28.91^{\mathrm{a}}$ & $\pm 8.12^{\mathrm{a}}$ \\
\hline \multirow{2}{*}{$\begin{array}{c}\text { TFC } \\
{\left[\mathrm{mg} 100 \mathrm{~mL}^{-1}\right]}\end{array}$} & 48.21 & 31.03 & 28.29 & 30.86 & 13.39 & 9.84 & 32.68 \\
\hline & $\pm 1.51^{\mathrm{e}}$ & $\pm 1.07^{\mathrm{d}}$ & $\pm 1.27^{\mathrm{c}}$ & $\pm 2.20^{\mathrm{d}}$ & $\pm 1.27^{\mathrm{b}}$ & $\pm 1.49^{\mathrm{a}}$ & $\pm 2.56^{\mathrm{d}}$ \\
\hline \multirow{2}{*}{ TEC $\left[{ }^{\circ} \mathrm{Bx}\right]$} & 10.78 & 10.17 & 9.97 & 10.06 & 10.10 & 10.00 & 10.13 \\
\hline & $\pm 0.23^{\mathrm{a}}$ & $\pm 0.18^{\mathrm{a}}$ & $\pm 0.15^{\mathrm{a}}$ & $\pm 0.10^{\mathrm{a}}$ & $\pm 0.09^{\mathrm{a}}$ & $\pm 0.15^{\mathrm{a}}$ & $\pm 0.10^{\mathrm{a}}$ \\
\hline \multirow[b]{2}{*}{$a_{w}$} & 0.990 & 0.993 & 0.993 & 0.985 & 0.991 & 0.991 & 0.987 \\
\hline & $\pm 0.00^{\mathrm{bc}}$ & $\pm 0.001^{\mathrm{d}}$ & $\pm 0.002^{\mathrm{d}}$ & $\pm 0.002^{\mathrm{a}}$ & $\pm 0.001^{\mathrm{cd}}$ & $\pm 0.001^{\mathrm{cd}}$ & $\pm 0.001^{\mathrm{ab}}$ \\
\hline \multirow{2}{*}{$\begin{array}{c}\text { Vulg-I } \\
{\left[\mathrm{mg} \mathrm{mL}^{-1}\right]}\end{array}$} & 0.230 & 0.214 & 0.195 & 0.218 & 0.217 & 0.212 & 0.195 \\
\hline & $\pm 0.002^{\mathrm{b}}$ & $\pm 0.003^{\mathrm{ab}}$ & $\pm 0.001^{\mathrm{a}}$ & $\pm 0.001^{\mathrm{ab}}$ & $\pm 0.001^{\mathrm{ab}}$ & $\pm 0.002^{\mathrm{ab}}$ & $\pm 0.002^{\mathrm{a}}$ \\
\hline \multirow{2}{*}{$\begin{array}{l}\text { Betanin } \\
{\left[\mathrm{mg} \mathrm{mL}^{-1}\right]}\end{array}$} & 0.275 & 0.305 & $0.329 \pm$ & 0.367 & 0.351 & 0.348 & 0.334 \\
\hline & $\pm 0.014^{\mathrm{a}}$ & $\pm 0.029^{\mathrm{ab}}$ & $0.011^{\mathrm{bc}}$ & $\pm 0.014^{\mathrm{c}}$ & $\pm 0.005^{\mathrm{c}}$ & $\pm 0.016^{\mathrm{c}}$ & $\pm 0.024^{\mathrm{c}}$ \\
\hline
\end{tabular}

Explanatory notes: TPC -total content of polyphenolic compounds; TFC- total content of flavonoid compounds; TECtotal extract content; $\mathrm{a}_{\mathrm{w}}$ - water activity, Vulg-I- the content of vulgaxanthin-I. The results are presented as mean values with error bars representing standard deviation $(\overline{\mathrm{x}} \pm \mathrm{s} / \mathrm{SD})$. The differences between the mean values indicated by the various letter in the same row (analyzed parameter) are statistically significant $(\mathrm{p}<0.05)$.

The obtained results of the $\mathrm{pH}$ changes in the beetroot juices are in agreement with the findings reported by Jagannath et al. (2014), who applied $L$. plantarum and $L$. delbrueckii in beetroot fermentation intending to stabilize the betanin content. They recorded a rapid decrease in $\mathrm{pH}$ after 48-h fermentation with the $L$. plantarum strain from $\mathrm{pH}=6.5$ (fresh beetroot sample) to $\mathrm{pH}<4.4$. In our study, both strains demonstrated the capability of dynamic acidification of the beet juice, reducing the level of $\mathrm{pH}$ from 6.11 to $3.85 \pm 0.02$ (strain EK11) and $\mathrm{pH}=3.82 \pm 0.01$ (probiotic strain) during the 24-h fermentation.

The beetroot juices characterized by low $\mathrm{pH}$ values (Table 3) exhibited also lower content of vulgaxanthin-I. In addition, the concentrations of this yellow pigment were significantly lower $(p<0.05)$ in all fermented beet juices than in the unfermented products (control).

It might be suggested the changes in $\mathrm{pH}$ influence the stability of some bioactive substances present in vegetable raw materials. It has been indicated that betanins present in beetroot are converted to neobetanin at low $\mathrm{pH}$, whereas alkaline conditions lead to the conversion of betanins into colorless cyclo-DOPA and bright yellow betalamic acid (Stintzing and Carle 2004). This indicates that lactic acid generated during fermentation by the $L$. plantarum strains in the analyzed products reduced the $\mathrm{pH}$ level in the beetroot drinks, causing recondensation of cyclo-DOPA and betalamic acid molecules (Klewicka, 2012). Moreover, as in Czyżowska et al. (2006), the present results showed that the changes in the concentrations of pigments in the beet juices varied, depending on the type of raw material subjected to fermentation as well as bacteria composition in the applied starter culture. It has been suggested that fermentation may enhance isomerization and dehydrogenation of betanin, which is determined by the activity of microbial enzymes (Czyżowska et al., 2006). Since glucose molecules are important components of betacyanins, changes in the red pigment contents in beet juices during fermentation might also be related to differences in the effectiveness of sugar utilization by the tested L. plantarum strains used as starter cultures. Furthermore, Czyżowska et al. (2006) revealed that the use of a properly selected fermentation starter culture might favor the preservation of a high level of betacyanins in relation to the initial concentration of these compounds in the fresh product. Similar findings were described by Jagannath et al. (2014), who reported that fermentation of beet juice by L. plantarum (NCIM 2083) contributed to the preservation of substantial amounts of betanins in the final product. In our study, the fermentation by the L. plantarum strains yielded a high concentration of these bioactive substances in the fermented beetroot juices. The different tendencies in the changes between the content of betains and vulgaxanthin-I during fermentation in the juices analyzed in our study might be explained by the considerably lower resistance to low $\mathrm{pH}$ values exhibited by the yellow pigments vs. the red ones (Klewicka, 2012). The fermentation process was shown to increase the lycopene content in the tomato juices (Table 2). The highest concentration of this biocomponent was found in the cold-stored final products, with the highest value in tomato juices fermented by the probiotic strain). The highest amounts of this 
component in the cold-stored final products (in comparison to samples from earlier production stages) might be associated with the longer time of extraction and exposure to bacterial enzymes involved in releasing this compound from residues of plant cells. This is in agreement with the results reported by Bartkiene et al. (2013), who demonstrated that a low $\mathrm{pH}$ value of fermented juices was related to a higher content of lycopene in tomato beverages. Similar observations were recorded by Ranveer et al. (2013), who indicated that the fermentation process significantly enhanced the availability and concentration of lycopene in the final product. This is explained by the enzymatic activity of bacteria in the fermentation process, which had a positive effect on the degradation of the components of the plant cell walls, enhancing the release of intracellular lycopene and increasing the level of this bioactive substance in fermented tomato juices (Ranveer et al., 2013; Jamal et al., 2017).

Different trends in antioxidant activity changes were observed in the juices fermented by the two L. plantarum strains (Figure 2 and Figure3). The tomato juices fermented by the probiotic strain exhibited higher values of antioxidant activity after the 48-h fermentation than after $24 \mathrm{~h}$. The EK11containing beverages exhibited higher inhibition values after the 24-h than 48-h fermentation (Figure 3). In turn, beetroot juices fermented by the strain 299v exhibited a stronger free radical scavenging ability after $48 \mathrm{~h}$ than $24 \mathrm{~h}$ (Figure 2), in contrast to the products fermented by $L$. plantarum EK11 (higher values after the 48-h than 24-h fermentation).

Generally, the beetroot drinks exhibited higher DPPH radical scavenging activities, with inhibition from the range $71.58 \pm 5.96 \%$ (cold-stored EK11fermented juices) to $89.00 \pm 2.44 \%$ (beverages fermented for $24 \mathrm{~h}$ by the probiotic $299 \mathrm{v}$ strain) than tomato juices (Figure 2 and Figure 3). The values of this parameter in the latter juices ranged from $53.63 \pm 4.06 \%$ (cold-stored EK11-fermented product) to $79.45 \pm 1.41 \%$ (juices fermented for 24 $\mathrm{h}$ by the probiotic strain).

The differences in the antioxidative activity between the variants of $L$. plantarum-fermented vegetable juices may be associated with the different effectivity of the strains in bioconversion of antioxidative components and may be influenced by the different specificity of the fermented food matrix (diverse chemical compositions of the raw materials). These findings are consistent with the results described by Nazzaro et al. (2008), who indicated a similar trend in the analysis of carrot juices fermented by different lactic acid bacteria. They reported a decrease in the DPPH radical scavenging activity in products fermented with L. rhamnosus, while the use of $L$. bulgaricus increased the values of this parameter. However, Huang et al. (2019) and Hur et al. (2014) showed that the fermentation process increased the antioxidant activity of fermented plant-derived material. This agrees with the results noted for beetroot juices fermented for $24 \mathrm{~h}$ by the probiotic strain and beverages fermented for $24 \mathrm{~h}$ by $L$. plantarum EK11 (the antioxidative activities of these variants were significantly higher than in the unfermented juices and the positive control) and for tomato juices fermented by L. plantarum $299 \mathrm{v}$ for $48 \mathrm{~h}$. Similar observations were described by Ronghao et al. (2018), who reported that the DPPH radical scavenging activities of papaya juices after 48 -h fermentation by $L$. plantarum GIM1.140 increased by $4.63 \%$, reaching $83.1 \pm 1.9 \%$ inhibition.

In our study, reduced antioxidant activity was observed in all final products (after the 48-h fermentation and refrigerated storage). $\mathrm{Li}$ et al. (2019) noted that apple juice fermented by $L$. plantarum ATCC14917 for over 48h had lower DPPH scavenging activity than products analyzed in earlier phases of fermentation. Nonetheless, the radical scavenging activity of all fermented beetroot and tomato juices (regardless of the strain used culture) exceeded $50 \%$ of inhibition.

Furthermore, the findings suggesting that the fermentation process reduced the total extract content in both tomato and beet juices (Tables 2 and 3) is in agreement with the results shown by Seelam et al. (2017) for tomato and carrot juices. This may be explained by the high metabolic activity of bacterial strains utilizing dissolved substances (mainly sugars) for their growth, which is directly reflected in a reduced value of total extract in fermented juices.

The analyses also revealed that the cold-stored fermented tomato and beetroots juices had the lowest values of $a_{w}$ (Tables 2 and 3). However, no significant changes $(p>0.05)$ in the value of this parameter were observed in the vegetable juice samples analyzed at the different fermentation time points (Table 2 and Table 3). Noteworthy, the water activity value of the fermented products was not lower than the minimum value $\left(a_{w}=0.91 \%\right)$ required for proper growth of lactobacilli (Bonczar et al., 2011). This indicates that the growth of the tested strains was not inhibited by the environmental conditions during the fermentation process. It is worth mentioning that the cold-stored tomato juices were characterized by the higher content of flavonoid compounds (in comparison to 
the control variant), whereas an opposite effect was noted in the beetroot drinks (all fermented products had a lower TFC value than unfermented juice) (Table 2 and Table 3).

The present findings showing the lower value of TFC in the fermented than unfermented beetroot juice (opposite to that in the tomato-based drinks) are consistent with the results reported by $\mathrm{Li}$ et al. (2019), who noted a significant $34.8 \%$ decrease in TFC in apple juice subjected to lactic acid fermentation. A similar tendency was reported by Othman et al. (2009) in olives fermented by $L$. plantarum PTCC 1058. These observations may be explained by the metabolic activity of lactic acid bacteria (LAB) contributing to the conversion and depolymerization of some phenolic compounds present in juices (Mousavia, et al., 2013). Moreover, it has been indicated that the reduced levels of TPC and TFC in some plant-based fermented beverages may not exclude the possibility of an increase in the antioxidant activity of the products (Cai et al. 2006). This is associated with the fact that LAB are able to release glucose from the structure of phenolic compounds, leading to the generation of a higher number of hydroxyl groups. Additionally, some other metabolites formed through the fermentation of plant-derived juice may influence the antioxidant activity (Mousavia et al., 2013, Hashemi and Mahmoodi 2017). However, the differences between TPC, TFC, and antioxidative properties and the different changes in their value during fermentation observed in the products analyzed in our study may be associated with the individual properties of the bacterial strain used as a starter culture and also the specificity and different composition of the plant material used for the production of fermented juices.

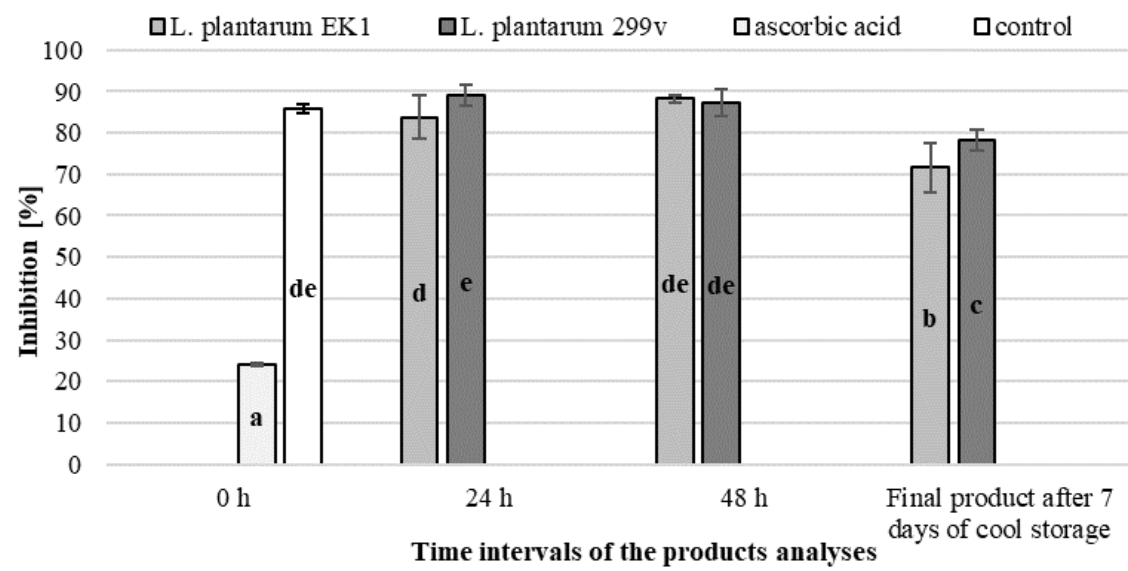

Figure 2. Comparison of the antioxidative properties of beetroot juice variants.

Explanatory notes: The antioxidant activity is expressed as the ability of the product to reduce the absorbance value of the DPPH free radical solution (\% inhibition). The results are mean values with error bars representing standard deviation $(\overline{\mathrm{x}} \pm \mathrm{S} / \mathrm{SD})$. The differences between the mean values indicated by the different letters are statistically significant $(\mathrm{p}<0.05)$; control - pasteurized unfermented juice variant; ascorbic acid $(0.2 \mathrm{mM})$ - positive control.

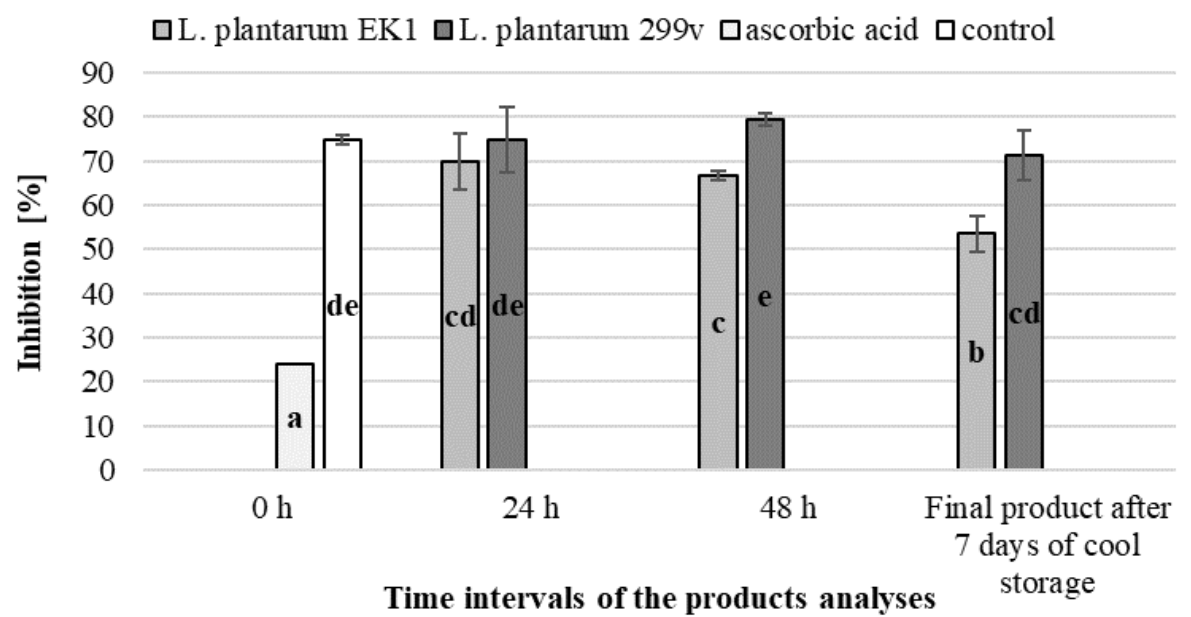

Figure 3. Comparison of the antioxidative properties of tomato juice variants.

Explanatory notes: The antioxidant activity is expressed as the ability of the product to reduce the absorbance value of the DPPH free radical solution (\% inhibition). The results are mean values with error bars representing standard deviation $(\overline{\mathrm{x}} \pm \mathrm{s} / \mathrm{SD})$. The differences between the mean values indicated by various letter are statistically significant $(\mathrm{p}$ $<0.05)$; control - pasteurized unfermented juice variant; ascorbic acid $(0.2 \mathrm{mM})$ - positive control 
Nonetheless, further comprehensive research is required for a better understanding of the causes of these changes.

Current metabolomic analyses conducted in conjunction with microbial ecology/genomic studies have great potential in identifying new desirable starter bacterial cultures and new bioactive compounds from fermented foods, such as the novel strain isolated from spontaneously fermented white button mushrooms analyzed in this study. The results of the preliminary analyses presented in this paper indicate the technological and functional potential of the new strain. However, there are still many questions to be answered in further detailed studies on the

\section{CONCLUSIONS}

The new strain Lactiplantibacillus plantarum EK11 isolated from spontaneously fermented white button mushrooms exhibits technological potential to be applied as a starter monoculture in the fermentation of vegetable juices. Lactic acid fermentation of vegetable beverages with the use of the analyzed native strain may be an attractive means of enhancing the functional properties of various vegetable-derived products including juices. In the present preliminary study, the novel strain exhibited high technological and functional potential comparable to that of probiotic strains. $L$. properties of $L$. plantarum EK11 and foods fermented by the strain (including plant-based beverages), especially in the context of biomarkers of the health benefits of functional fermented foodstuffs. They are related to the stability of the products and the amount and frequency of consumption thereof required for the induction of health benefits. The bioavailability of valuable bioactive components to the human organism is also a pivotal issue. Therefore, the promising results of the present preliminary investigations encourage the continuation of the analysis of the potential application of $L$. plantarum EK11 in the food fermentation industry.

plantarum EK11 has genetic determinants of the production of bacteriocins. Moreover, the tomato and beetroot juices fermented by this strain exhibited high content of bioactive components, e.g. polyphenolic compounds, lycopene, or betalains. The beverages were also characterized by high antioxidant activity. Furthermore, the novel strain demonstrates the ability to ferment plant material in a wide range of initial $\mathrm{pH}$. Therefore, the preliminary results encourage investigations aimed at the wider characterization of the strain and assessment of the possibility of its practical application as starter cultures in the production of plant-based fermented foods.

\section{Acknowledgments}

The investigation was funded by Project financed under the program of the Minister of Science and Higher Education under the name "Regional Initiative of Excellence" in 2019-2022 project number 029/RID/2018/19 funding amount 11927330.00 PLN.

\section{REFERENCES}

1. Acosta-Estrada, B.A., Gutiérrez-Uribe, J.A. \& Serna-Saldívar, S.O. (2014). Bound phenolics in foods, a review. Food Chem. 152, 46-55. doi: 10.1016/j.foodchem.2013.11.093.

2. Adejo, G.O., Agbali, F.A. \& Otokpa, O. S. (2015). Antioxidant, Total Lycopene, Ascorbic Acid and Microbial Load Estimation in Powdered Tomato Varieties Sold in Dutsin-Ma Market. OALib Journal, 2, e1768. doi: http://dx.doi.org/10.4236/oalib.1101768.

3. Anderssen E.L, Diep, D.B., Nes, I.F., Eijsink, V.G.H. \& Nissen-Meyer J. (1998). Antagonistic activity of Lactobacillus plantarum C11: two new two-peptide bacteriocins, plantaricins EF and JK, and the induction factor plantaricin A. Appl. Environ. Microbiol., 64(6),2269-72. doi: 10.1128/AEM.64.6.22692272.1998.

4. Bartkiene, E., Vidmantiene, D., Juodeikiene, G., Viskielis, P. \& Urbanoviciene, D. (2013). Lactic Acid Fermentation of Tomato: Effects on cis/trans Lycopene Isomer Ratio, b-Carotene Mass Fraction and Formation of L(+)- and D(-)-Lactic Acid. Food Technol. Biotechnol., 51(4), 471-478.

5. Bonczar, G., Wszołek, M., Walczycka, M., Żebrowska, A. \& Maciejowski, K. (2011). Wpływ wybranych czynników na aktywność wody i jakość mikrobiologiczną miękkich serów z mleka owczego. Żywność. Nauka. Technologia. Jakość. 3(76), 98-108. (In Polish). 
6. Cai, Y.Z., Sun, M., Xing, J., Luo, Q. \& Corke, H. (2006). Structure-radical scavenging activity relationships of phenolic compounds from traditional Chinese medicinal plants. Life Sci., 78(25), 287288. doi: 10.1016/j.lfs.2005.11.004

7. Czyżowska, A., Klewicka, E. \& Libudzisz, Z. (2006). The influence of lactic acid fermentation process of red beet juice on the stability of biologically active colorants. Eur. Food Res. Technol., 223, 110-116. https://doi.org/10.1007/s00217-005-0159-y

8. Di Cagno, R., Coda, R., De Angelis, M., \& Gobbetti, M. (2013). Exploitation of vegetables and fruits through lactic acid fermentation. Food Microbiol., 33(1), 1-10. https://doi.org/10.1016/j.fm.2012.09.003.

9. Di Cagno, R., Filannino, P. \& Gobbetti, M. (2016). Fermented foods: fermented vegetables and other products, In: Encycl. Food Health, Caballero, B., Finglas, P.M. \& Toldrá, F. (Eds.), pp. 668-674, Elsevier, Academic Press. https://doi.org/10.1016/B978-0-12-384947-2.00284-1.

10. El-Fattah, A., Sakr, S., El-Dieb, S. \& Elkashef, H. (2016). Angiotensin-converting enzyme inhibition and antioxidant activity of commercial dairy starter cultures. Food Sci. Biotechnol., 25(6), 1745-1751. doi: 10.1007/s10068-016-0266-5.

11. El-Sayed, A.A., Rabie, M. A., El-Maaty, S. M. A. \& El-Nemr, S.E.A. (2018). Fermented tomato juice (Lycopersicon esculentum mill.) produced via lactic acid bacteria during cold storage. Carpath. J. Food Sci. Technol., 10(1), 5-18.

12. Galanis, A., Kourkoutas, Y., Tassou, Ch.C. \& Chorianopoulos, N. (2015). Detection And Identification Of Probiotic Lactobacillus Plantarum Strains By Multiplex Pcr Using Rapd-Derived Primers. Int. J. Mol. Sci., 16(10), 25141-25153. doi: 10.3390/ijms161025141.

13. Garcia, C., Guerine M., Souidi K. \& Remize F. (2020). Lactic Fermented Fruit or Vegetable Juices: Past, Present and Future. Beverages., 6(1), 8; https://doi.org/10.3390/beverages6010008.

14. Gościnna, K., J. Czapski, J. Mikołajczyk-Bator, K. \& Kidoń, M. (2012). Content betalain pigments, nitrates and antioxidant capacity of beetroot juices depending on cultivars and the size of beetroot roots. Apar. Badaw. Dydakt. 17(3), 85-90. (In Polish).

15. Guldiken, B., Toydemir, G., Nur, M.K., Okur, S., Boyacioglu, D. \& Capanoglu, E. (2016). HomeProcessed Red Beetroot (Beta vulgaris L.) Products: Changes in Antioxidant Properties and Bioaccessibility. Int. J. Mol. Sci., 17(6),858. doi:10.3390/ijms17060858.

16. Halwani, A.F., Sindi, H.A. \& Jambi H.A. (2018). Characterization of physical properties of red beet pigments. J. Biochem. Tech., 9(3), 10-14.

17. Hashemi, S.M.B. \& Mahmoodi, M. (2017). Fermentation of Barberry Juice to Produce Probiotic Beverage. Curr. Nutr. Food Sci., 13(3), 204-211. DOI: 10.2174/1573401313666170118123128

18. Huang, Y., Wang, H. \& Zhu, C. (2019). Effect of Lactic Acid Bacteria Fermentation on Antioxidation and Bioactivity of Hawthorn Pulp. IOP Conf. Ser.: Earth Environ. 267(6), 062056. doi:10.1088/17551315/267/6/062056

19. Hur, S.J., Lee, S.Y., Kim, Y.C., Choi, I. \& Kim, G.B. (2014). Effect of fermentation on the antioxidant activity in plant-based foods. Food Chem. 160, 346-356. doi: 10.1016/j.foodchem.2014.03.112.

20. Jabłońska-Ryś, E., Skrzypczak, K., Sławińska, A., Radzki, W. \& Gustaw, W. (2019). Lactic acid fermentation of edible mushrooms: tradition, technology, current state of research: A Review. Compr. Rev. Food Sci. Food Saf., 18(3), 265-669. https://doi.org/10.1111/1541-4337.12425.

21. Jagannath, A., Kumar, M. \& Raju P.S. (2014). Fermentative Stabilization of Betanin Content in Beetroot and Its Loss during Processing and Refrigerated Storage. J. Food Process. Preserv., 39(6), 606-613. https://doi.org/10.1111/jfpp.12267

22. Jamal P., Hashlamona, A., Jaswir, I., Akbar, I. \& Nawawi, W.M.F.W. (2017). Extraction of lycopene from tomato waste using solid state fermentation. Int. Food Res. J., 25(Suppl), 416-421.

23. Klewicka E. (2012). Betacyjaniny- biodostępność i biologiczna aktywność. Żywność. Nauka. Technologia. Jakość 2 (81), 5-21.

24. Kumariya, R., Garsa, A.K., Rajput, Y.S., Sood, S.K., Akhtar, N. \& Patel, S. (2019). Bacteriocins: Classification, synthesis, mechanism of action and resistance development in food spoilage causing bacteria. Microb. Pathog., 128, 171-177. https://doi.org/10.1016/j.micpath.2019.01.002.

25. Li, Z., Teng, J., Lyu, Y., Hu, X., Zhao, Y., \& Wang, M. (2019). Enhanced Antioxidant Activity for Apple Juice Fermented with Lactobacillus plantarum ATCC14917. Molecules, 24(1), 51. https://doi.org/10.3390/molecules24010051

26. Mousavia, Z.E., Mousavia, S.M., Razavia, S.H., Hadinejada, M., Emam-Djomeha, Z. \& Mirzapoura, M. (2013). Effect of Fermentation of Pomegranate Juice by Lactobacillus plantarum and Lactobacillus 
acidophilus on the Antioxidant Activity and Metabolism of Sugars, Organic Acids and Phenolic Compounds. Food Biotechnol. 27(1), 1-13. DOI: 10.1080/08905436.2012.724037.

27. Mustopa, A.Z., Murtiyaningsih H., Fatimah, F. \& Suharsono S. (2016). Cloning and Heterologous Expression of Extracellular Plantaricin F Produced by Lactobacillus plantarum S34 Isolated from "Bekasam" in Lactococcus lactis. Microbiol. Indones., 10(3), 95-106. https://doi.org/10.5454/mi.10.3.3

28. Nazzaro, F., Fratianni, F., Sada, A. \& Orlando, P. (2008). Synbiotic potential of carrot juice supplemented with Lactobacillus spp. and inulin or fructooligosaccharides. J. Sci. Food Agric., 88(13), 2271-2276. Https://Doi.Org/10.1002/Jsfa.3343

29. Othman, N.B., Roblain, D., Chammen, N., Thonart, P. \& Hamdi, M. (2009). Antioxidant phenolic compounds loss during the fermentation of Chétoui olives. Food Chem., 116(3), 662-669. https://doi.org/10.1016/j.foodchem.2009.02.084

30. Panghal, A., Virkar, K., Kuma,r V., Dhull, S.B., Gat, Y. \& Chhikara N. (2017). Development of Probiotic Beetroot Drink. Curr. Res. Nutr. Food Sci., 5(3), 257-262. http://dx.doi.org/10.12944/CRNFSJ.5.3.10.

31. PN-90/A-75101/02. Przetwory owocowe i warzywne. Przygotowanie próbek i metody badań fizykochemicznych. Oznaczanie zawartości ekstraktu ogólnego. (In Polish)

32. Ranveer, R.C., Patil, S.N. \& Sahoo, A.K. (2013). Effect of different parameters on enzyme-assisted extraction of lycopene from tomato processing waste. Food Bioprod. Process., 91(4), 370-375. https://doi.org/10.1016/j.fbp.2013.01.006

33. Rizzello, C.G., Filannino, P., Di Cagno, R., Calasso, M. \& Gobbetti, I M. (2014). Quorum-Sensing Regulation of Constitutive Plantaricin by Lactobacillus plantarum Strains under a Model System for Vegetables and Fruits. Appl Environ Microbiol. 80(2), 777-787. doi:10.1128/aem.03224-13

34. Rojo-Bezares, B., Saenz, Y., Navarro, L., Zarazaga, M., Ruiz-Larrea, F. \& Torres, C. (2007). Cocultureinducible bacteriocin activity of Lactobacillus plantarum strain J23 isolated from grape must. Food Microbiol., 24(5), 482-491. DOI: 10.1016/j.fm.2006.09.003.

35. Ronghao, C., Wenxue, C., Haiming, C., Guanfei, Z. \& Weijun, C. (2018). Comparative Evaluation of the Antioxidant Capacities, Organic Acids, and Volatiles of Papaya Juices Fermented by Lactobacillus acidophilus and Lactobacillus plantarum. J. Food Qual., 2018, Article ID 9490435, 1-12. https://doi.org/10.1155/2018/9490435

36. Seelam, N.S., Akula, H., Katike, U., Obulam, V.S.R. (2017). Production, characterization and optimization of fermented tomato and carrot juices by using Lysinibacillus sphaericus isolate. J. Appl. Biol. Biotechnol., 5 (4), 66-75. DOI: 10.7324/JABB.2017.50410

37. Skrzypczak, K., Gustaw, K., Jabłońska-Ryś, E., Sławińska, A., Gustaw, W. \& Winiarczyk, S. (2020). Spontaneously fermented fruiting bodies of Agaricus bisporus as a valuable source of new isolates of lactic acid bacteria with functional potential. Foods, 9(11), 1631. https://doi.org/10.3390/foods9111631.

38. Stintzing, F.C. \& Carle, R. (2004). Functional properties of anthocyanins and betalains in plants, food and in human nutrition. Trends in Food Sci. Technol. 15(1), 19-38. https://doi.org/10.1016/j.tifs.2003.07.004

39. Suwanaruang, T. (2016). Analyzing Lycopene Content in Fruits. Agric. Agric. Sci. Procedia, 11, $46-48$. https://doi.org/10.1016/j.aaspro.2016.12.008

40. Szutowska, J. \& Gwiazdowska, D. (2020). Probiotic potential of lactic acid bacteria obtained from fermented curly kale juice. Arch. Microbiol., 203, 975-988. https://doi.org/10.1007/s00203-020-02095$\underline{4}$

41. Torres, S., Verón, H., Contreras, L.\& Isla, M.I. (2020). An overview of plant-autochthonous microorganisms and fermented vegetable foods. Food Sci. Hum. Well., 9(2), 112-123. https://doi.org/10.1016/j.fshw.2020.02.006 .

42. Vera-Pingitore, E., Jimenez, M. Eugenia, Dallagnol, A., Belfiore, C., Fontana, C., Fontana, P., von Wright, A., Vignolo, G., \& Plumed-Ferrer, C. (2016). Screening and characterization of potential probiotic and starter bacteria for plant fermentations. LWT - Food Sci. Technol., 71, 288-294. https://doi.org/10.1016/j.lwt.2016.03.046.

43. Yang, S.C., Lin, C.H., Sung, C.T. \& Fang, J.Y. (2014). Antibacterial activities of bacteriocins: application in foods and pharmaceuticals. Front Microbiol., 5:241. Erratum in: Front Microbiol. 2014;5:683. doi: 10.3389/fmicb.2014.00241.

44. Yoon, K.Y., Woodams, E.E. \& Hang, Y.D. (2004). Probiotication of tomato juice by lactic acid bacteria. J. Microbiol., 42(4), 315-318. 